\title{
'Take it or Go to Court' \\ - The Impact of Sec. 1a of the German Protection against Dismissal Act on Severance Payments -
}

\author{
Laszlo Goerke \\ Markus Pannenberg
}

CESIFO WORKING PAPER No. 3120

CATEGORY 4: LABOUR MARKETS

JULY 2010
An electronic version of the paper may be downloaded
- from the SSRN website:
- from the RePEc website:
www.SSRN.com
www.RePEc.org
- from the CESifo website:
www.CESifo-group.org/wp




\title{
'Take it or Go to Court' \\ - The Impact of Sec. 1a of the German Protection against Dismissal Act on Severance Payments -
}

\begin{abstract}
In 2004, a section was added to the German Protection against Dismissal Act, establishing a new procedure to dismiss an employee, given a predetermined severance payment. Most legal scholars presume the change to be without impact, while a minority of experts claims it to be either beneficial or unfavourable to employees. Our theoretical model suggests that firms will use the new procedure, but that the change in payoffs is indeterminate and, therefore, an empirical issue. Exploiting the fact that collective dismissals are not directly affected by the amendment, difference-in-differences estimates based on panel data for West Germany indicate that the legal change did have a negative effect on severance pay.
\end{abstract}

JEL-Code: J65, K31, C23.

Keywords: panel data, Protection against Dismissal Act, severance pay.

Laszlo Goerke

Department of Economics

Eberhard Karls University Tübingen

Melanchthonstrasse 30

72074 Tübingen

Germany

Laszlo.Goerke@uni-tuebingen.de
Markus Pannenberg

University of Applied Sciences Bielefeld

Department of Business and Economics

Universitätsstrasse 25

33615 Bielefeld

Germany

Markus.Pannenberg@fh-bielefeld.de

This version: 28.06.2010

We are grateful to Malte Mosel, Wendy Smith as well as to seminar participants in Duisburg and at CESifo (Munich) for helpful comments. 


\section{Introduction}

Employment protection legislation in Germany is generally regarded as comparatively strict. In addition, the number of dismissals resulting in labour court cases is relatively high (Bertola, Boeri and Cazes 1999; OECD 2004). The overwhelming majority of these cases results in a termination of the employment contract, often involving severance payments (Höland, Kahl and Zeibig 2007, pp. 183, 202). In response to these features, the main law regulating dismissals in Germany, the Protection against Dismissal Act (PaDA), was amended in 2004. In particular, a clause was added (PaDA Sec. 1a) which allows a firm to terminate a regular employment contract if, first, it makes a severance payment of a predetermined magnitude and, second, the employee does not object to the dismissal. Since the new section was added to the law, yet all other regulations remained in place, the government explicitly argued that "employee and employer need not fear any deterioration of their legal position" (Deutscher Bundestag 2003a, p. 9). The majority of legal scholars hold the view that PaDA Sec. 1a will not be applied and will have no impact on individual dismissals because the legal situation effectively remains unchanged (cf. Spilger 2009). Alternatively, it is occasionally argued that the level of severance pay defined by PaDA Sec. 1a represents a minimum, since no employee has an incentive to accept a lower payment. Finally, trade unions have feared that the law's amendment will be disadvantageous to workers.

In this paper, we inquire which of the above evaluations is adequate. Since there is no comprehensive body of data on the legal source of a dismissal in Germany, we assess the effect of PaDA Sec. 1a indirectly by calculating the impact on observed severance payments. More precisely, we exploit the fact that PaDA Sec. 1a does not apply to collective dismissals in firms with more than 20 employees in which a works councils exists. Using a difference-indifferences (DID) approach and representative panel data for the years 2001 to 2006 for West Germany, we can identify the (short-run) effect of PaDA Sec. 1a on observed severance pay and thereby assess its consequences.

In the next section, we outline the legal rules governing dismissals in Germany and the amendment of the PaDA. We also summarise the discussion among legal scholars regarding the new norm and previous analyses of its impact. In Section 3 we develop a simple theoretical model which allows us to investigate the incentives for a firm to proceed in accordance with PaDA Sec. 1a. For a subgroup of dismissed workers which we can identify in our empirical analysis, we derive a simple condition determining the change in severance payments. Additionally, the introduction of PaDA Sec. 1a is shown to have an ambiguous impact on the average payments. From a theoretical perspective, therefore, the new regulation 
may be beneficial or unfavourable to workers. In Section 4, we describe our data and outline our empirical strategy, and in Section 5 we report our findings. We observe an overall increase in average severance payments, while our DID-estimates indicate that payments resulting from mutual agreements between a firm and an employee and from individual dismissals have declined since 2004, relative to those paid in the case of collective dismissals. This suggests that firms indeed use the option of terminating an employment contract in accordance with PaDA Sec. 1a, and that those dismissed workers who may have been affected by the new regulation receive lower severance payments, relative to the amount they would have received without the law's amendment.

\section{Legal Background}

\subsection{Employment Protection Legislation and Further Regulations}

In the context of German individual labour law, the Civil Code and, in particular, the Protection against Dismissal Act (PaDA) govern the termination of regular employment contracts. ${ }^{1}$ The Civil Code Sec. 622 stipulates a notice period for ordinary dismissals for all employees whose trial period of no more than 6 months has expired, which increases with tenure. However, periods of employment taking place before an individual has reached the age of 25 are not taken into account. In addition, Civil Code Sec. 626 governs extraordinary (i.e. summary) dismissals.

PaDA Sec. 1(1) states that the termination of an employment contract that has existed for more than 6 months becomes void if it is socially unjustifiable. A dismissal is deemed socially unjustifiable which "is not based upon reasons pertaining to the person or the behaviour of the employee, or on urgent operational requirements that are an obstacle to the employee remaining employed by the establishment." 2 In the case of operational dismissals, the selection of employees to be made redundant must take place on the basis of specific criteria (so-called social selection; PaDA Sec. 1(3)), which currently include tenure, age, alimony obligations, and severe disabilities.

An employee can, claiming that the dismissal is socially unjustifiable or void on other grounds, sue the firm to obtain a judgement that the employment contract has not ceased. According to the Labour Court Law, Sec. 54, the first step in the ensuing court procedure is a

\footnotetext{
${ }^{1}$ In addition, there are special regulations, for example, for the disabled, employees taking maternity or parental leave, members of works councils and apprentices.

${ }^{2}$ This and all other translations of legal sources from German have been rendered by the authors.
} 
conciliatory hearing. During this hearing, the judge will, in many cases, propose an amicable settlement. If no such settlement can be found, a second hearing is arranged. Here, too, it is often the case that attempts are made to end the lawsuit via an amicable settlement. In cases dealt with by labour courts, each party generally bears the costs of the legal dispute itself. Furthermore, representation by a lawyer is not compulsory (Labour Court Law, Sec. 11, 12a).

Even if the labour court decides that the dismissal was void, it is unlikely that employment will continue. ${ }^{3}$ According to PaDA Sec. 9, the court has the option of terminating the contract, either if continuation of employment is not to be expected of the employee, or if "further cooperation between employer and employee serving the objectives of the firm" cannot be expected. Only in this case a verdict must include an "appropriate severance payment". In the PaDA there are no detailed specifications regarding its amount. PaDA Sec. 10 stipulates only an upper limit of 12 monthly salaries, which increases to 15 (18) monthly salaries for employees who have reached the age of 50 (55) and have a tenure of at least 15 (20) years.

At the beginning of 2004, the PaDA was altered. In particular, it may now basically be applied only to employees who work in firms which will typically have 10 or more staff (Sec. 23(I)), and no longer to firms with between 5 and 10 employees. In addition to further amendments, a new clause - Sec. $1 \mathrm{a}$ - was added:

"(1) If an employer dismisses an employee on the basis of urgent operational requirements ..., and if the employee takes no legal action ... before the deadline laid down in Sec. 4 Sentence 1, then the employee becomes entitled to severance pay upon the expiration of the notice period. The employer is required to state in the dismissal notification that the dismissal is due to urgent operational requirements and that the employee can claim the severance payment as a result of allowing the period to elapse during which the employer can be sued.

(2) The amount of severance pay is equal to 0.5 monthly salaries for each year of employment. ...."

Sentence 1 restricts the applicability to urgent operational reasons. However, the second sentence qualifies this restriction, stating that the employer is to refer to such a requirement but not, however, that it necessarily constitutes the actual reason for the dismissal. Indeed, the opinion is widely held that if an employer has made the required reference and the employee has not filed a suit, there is an entitlement to severance pay, irrespective of whether or not the dismissal is due to operational requirements. ${ }^{4}$

\footnotetext{
${ }^{3}$ For 2003, Höland et al. (2007, pp. 202 ff) calculate an upper limit of $15 \%$ for the probability that a dismissal protection case led to a revocation of the dismissal, but conjecture that the actual proportion of continuing employment contracts is considerably lower.

${ }^{4}$ Cf., e.g., Maschmann (2003, p. 7), Bader (2004, p. 71), Däubler (2004, p. 178), Preis (2004, p. 73), Quecke (2004, p. 95), Tschöpe (2004, p. 197), Raab (2005, p. 6), Hoyningen-Huene and Linck (2007, p. 368), and
} 
Collective labour law also contains a series of guidelines related to dismissal protection rights. If a works council exists, it must be heard before each dismissal according to the Works Constitution Act (WCA) Sec. 102. Otherwise, the dismissal becomes void. There are additional regulations for collective dismissals. WCA Sec. 112 states that "in firms with generally more than 20 employees entitled to elect a works council, the management must inform the works council in a comprehensive and timely manner about planned operational changes that could entail considerable disadvantages for the workforce or substantial parts of the workforce, and must evaluate the planned operational changes together with the works council." Furthermore, WCA Sec. 112a explicitly states that if a planned operational change consists solely of the dismissal of workers, the company is obliged to arrange a so-called social plan if the number of dismissed workers due to operational reasons exceeds certain thresholds. The social plan will typically contain guidelines on severance payments. If the works council and the employer cannot agree on the contents of a social plan, WCA Sec. 112 entrusts an arbitration committee with the resolution of the conflict. Furthermore, in the case of collective dismissals, employers will not have to establish a social plan if there is no works council, ${ }^{5}$ but in its presence cannot circumvent this obligation by offering employees a severance payment in accordance with PaDA Sec. 1a. ${ }^{6}$ Therefore, PaDA Sec. 1a is unlikely to have an impact on the level of severance payments in the case of collective dismissals in firms with 20 or more employees in which a works council exists. We use this fact in our differences-in-differences specification to assess the causal effect of PaDA Sec. 1a on severance payments. Note, however, that in 2009 , works councils existed in only $10 \%$ of all private sector firms employing five or more workers in West Germany. These firms employed $45 \%$ of all workers (Ellguth and Kohaut 2010). The latter fraction declined from 50\% in 2001 to $47 \%$ in 2004, when the PaDA was amended, and rises with firm size.

Also relevant to this study are legal changes regarding unemployment benefits and the taxation of severance pay that came into effect during the period covered by our empirical investigation. At the beginning of 2005, income-related unemployment assistance primarily paid to long-term unemployed was replaced by a flat-rate so-called Arbeitslosengeld II, and

Spilger (2009, pp. 235 f). Rolfs (2006) evidently holds a different opinion. Hergenröder (2009, PaDA Sec. 1a, para. 9-19, 30) essentially agrees with the view that only the reference to the reason for the dismissal (Sentence 2) must deem it a redundancy, but points out that the employee must have the option to appeal in the case of malicious deception (see also Quecke 2004, p. 95 and Hesse 2007, para. 9a). Kögel (2009, p. 363) appears to completely rule out the possibility of an appeal.

${ }^{5}$ See, for example, Däubler, Kittner and Klebe (2008, p. 1977) or Fabricius (2010, p. 1587).

${ }^{6}$ See, for example, Spilger (2009, p. 258). However, if a social plan has been agreed upon and the firm then proposes to terminate the employment contract of an employee in accordance with PaDA Sec. 1a, this will be feasible if the resulting severance payment exceeds the payment determined according to the social plan. 
about a year later the maximum entitlement period for benefits - termed Arbeitslosengeld Iwas reduced for unemployed persons above the age of 45 years. The second important change from the perspective of our investigation is the reduction of the income tax exemption threshold for severance payments from about $€ 8,200$ to $€ 7,200$ on 1 January 2004 . For employees over 50 (55) years of age with a tenure of more than 15 (20) years, the corresponding threshold of roughly $€ 10,300$ ( $€ 12,300$ ) was reduced to $€ 9,000$ ( $€ 10,800$ ), that is, by larger absolute amounts than for the large majority of employees. At the start of 2006, the tax exemption thresholds for severance payments were completely abolished. Once again, the absolute reductions were larger for older employees with high tenure, where the relevant thresholds are defined by PaDA Sec. 10.

\subsection{Previous Analyses of PaDA Sec. 1a}

From a legal perspective, the dominant view of PaDA Sec. 1a is that it has not had and will not have an effect. ${ }^{7}$ The prevailing justification for this evaluation is that even before PaDA Sec. 1a was introduced, firms and employees had the option to agree on a severance payment as part of a mutual agreement to terminate the employment contract. As this option still exists, there are no incentives for firms to proceed in accordance with PaDA Sec. 1a. Rather, the legal situation remains essentially unchanged. ${ }^{8}$ Alternatively, it is claimed that an offer made according to PaDA Sec. 1a would be taken as a signal of the firm's uncertainty regarding the legal evaluation of the dismissal, constituting an invitation for the employee to take legal action. ${ }^{9}$ It is therefore occasionally proffered in the legal and also economic debate that a severance payment calculated according to PaDA Sec. 1a represents a lower limit. ${ }^{10}$ Only the Confederation of German Trade Unions held the opinion that the regulations for "the employee ... by no means [constitute] a profit", while employers were said to benefit (Deutscher Bundestag 2003b, p. 9). ${ }^{11}$

\footnotetext{
${ }^{7}$ See, e.g., Bauer and Krieger (2004, p. 79), Preis (2004, pp. 72, 79), Wolff (2004, p. 381), Raab (2005, p. 12), Rolfs (2006, p. 41), Hesse (2007, para. 2), Hoyningen-Huene and Linck (2007, p. 368), and Spilger (2009, p. 229). Merz (2006, pp. 213 f) and Kögel (2009, p. 367) are less sceptical.

${ }^{8}$ See, e.g., Maschmann (2003, 6), Preis (2004, pp. 71 f), and Kortstock (2007, p. 297).

${ }^{9}$ See Bader (2004, p. 70), Bauer and Krieger (2004, p. 77), Preis (2004, p. 75), Wolf (2004, p. 381) and Kögel (2009, p. 367). Merz (2006, p. 211) provides further references.

${ }^{10}$ See Maschmann (2003, 12), Bader (2004, p. 70), Tschöpe (2004, p. 199), Wolff (2004, p. 381), Jahn and Walwei (2005), Jahn (2009), and May and Schellhaaß (2009).

${ }^{11}$ This view was stated in a parliamentary hearing of the German parliament (the Bundestag). It should be noted that a similar view is expressed in a study by the Institut der deutschen Wirtschaft, a research institute associated with German employer confederations: "As ... severance payments according to PaDA Sec. 1a are also included in the calculations - the amount of which should generally lie beneath those otherwise paid - ... ." (Hardege and Schmitz 2008, p. 36, own translation).
} 
Until now, the impact of PaDA Sec. 1a has not been explored empirically, allowing for causal interpretations. Jahn (2009) analyses the determinants of the level of severance payments for the years 2000-2006 in West and East Germany. Her set-up includes a dummy for the years 2004-2006. She interprets the significant positive coefficient as evidence that the $2004 \mathrm{PaDA}$ reform established a lower limit for severance payments. Goerke and Pannenberg (2010b) investigate the so-called severance pay factor before and after the introduction of PaDA Sec. 1a, i. e. the multiple of the wage that is paid as severance payment per year of tenure. They show theoretically that severance pay factors are likely to bunch around 0.5 , the value defined by PaDA Sec. 1a, subsequent its introduction and find substantive descriptive evidence for such a development. However, their semi-parametric decomposition analysis does not permit a causal interpretation.

\section{Theoretical Analysis}

The theoretical investigation will focus on the firm's and employee's behaviour in the event of an individual dismissal in which PaDA Sec. 1a is in principle applicable. Initially, we will analyse the incentives for a firm to (1) dismiss an employee without a severance pay offer, (2) propose a mutual agreement including a severance payment determined in an optimal manner by the firm in order to avoid a legal conflict, or (3) use the procedure laid down in PaDA Sec. 1a. In each case, an employee dissatisfied with the firm's behaviour can file a labour court suit. Our model can, therefore, generate all major observable outcomes of an employerinitiated individual contract termination: that is, an outright dismissal without any financial compensation; a dismissal involving a payment by the firm, either because employer and employee mutually agreed on a contract termination including such a disbursement, or because of the procedure laid down in PaDA Sec. 1a; and finally, a court-induced compensation. We can show that all types of dismissals can arise subsequent to the modification of the PaDA. We derive a simple condition for the change in observed severance payments, conditional on these payments resulting from a non-controversial contract termination. By non-controversial we refer to a dismissal including a severance payment that resulted without a court's involvement. Finally we investigate the change in the average magnitude of severance payments. 


\subsection{Analytical Framework}

The starting point of our analysis is the firm's dismissal decision. Both the firm and the employee are risk-neutral. The firm minimises the expected costs resulting from a dismissal, while the employee maximises his expected payoff, consisting of direct payments and the monetary equivalent of non-monetary costs and gains.

Initially, a player labelled 'Nature' selects the firm's direct costs associated with the three options described above. In particular, Nature 'chooses' the costs $\mathrm{K}^{\mathrm{n}}, \mathrm{K}^{\mathrm{n}} \geq 0$, of dismissing an employee without a severance pay offer; the firm's costs $\mathrm{K}^{\mathrm{c}}, \mathrm{K}^{\mathrm{c}} \geq 0$, of obtaining legal advice and of legal representation in the event that the dismissed employee has filed a labour court suit; and the costs $\mathrm{K}^{\mathrm{s}}, \mathrm{K}^{\mathrm{s}} \geq 0$, arising if a mutual agreement including a voluntary payment is signed. The costs $\mathrm{K}^{\mathrm{n}}$ can, for example, occur because the remaining workforce's productivity is affected negatively by a dismissal of a former colleague without a compensatory payment being offered. Alternatively, costs $\mathrm{K}^{\mathrm{n}}$ can be positive because customers respond to dismissals by purchasing substitute products from competitors. The firm's cost $\mathrm{K}^{\mathrm{c}}$ of a court procedure will arise if the firm hires a lawyer or if staff from the personnel department need to prepare for and attend a court meeting. Finally, the costs $\mathrm{K}^{\mathrm{S}}$ can, for example, represent the expenditure for judicial advice which ensures that the mutual agreement cannot be legally disputed by the employee in order to obtain further payments. Since the firm's costs in addition to a severance payment are likely to be lower in the case of a mutual agreement than those resulting from a court procedure, we assume $\mathrm{K}^{\mathrm{s}} \leq \mathrm{K}^{\mathrm{c}}$. The costs $\mathrm{K}^{\mathrm{n}}, \mathrm{K}^{\mathrm{c}}$, and $\mathrm{K}^{\mathrm{s}}$ are public knowledge.

If the employee files a labour court suit, he will incur additional (opportunity) costs. These arise because of costly legal advice, the time needed for setting up the claim or because of a direct utility loss resulting from filing a suit. The monetary equivalent of these costs $\mathrm{k}$ is distributed uniformly on the interval $[0, \overline{\mathrm{k}}]$. While the employee is aware of the exact value of $\mathrm{k}$, the firm only knows the distribution when taking its decisions. We presume that the costs of a court procedure $\mathrm{k}$ and $\mathrm{K}^{\mathrm{C}}$ arise, irrespective of what the outcome of the suit is. Furthermore, with the exception of a severance payment, which will be specified below, any payments to the (former) employee, such as unemployment benefits, occurring subsequently to the dismissal, are assumed to be given and, accordingly, normalised to zero. 
Assume that the firm chooses the first option and dismisses the employee without a severance pay offer. Such an action creates costs $\mathrm{K}^{\mathrm{n}}$ to the firm, irrespective of the employee's response. If the employee consents, his payoff will be zero. However, if the employee does not accept the dismissal, this entails filing a labour court suit, claiming the dismissal to be socially unjustifiable. ${ }^{12}$ Since we cannot observe in our data whether or not an employee filed a suit and how the firm responded if this was the case, in the theoretical analysis we assume that the firm is unable to react to the employee's action. Moreover, we depict the whole court procedure in a highly simplified manner and suppose that the employee obtains a severance payment with a positive probability. Its expected value is denoted by $\mathrm{C}$. In consequence, the firm's expected costs, given a court procedure, equal $\mathrm{C}+\mathrm{K}^{\mathrm{c}}+\mathrm{K}^{\mathrm{n}}$, while the employee's expected payoff is given by $\mathrm{C}-\mathrm{k}$.

Suppose next that the firm proposes a mutual agreement, including a severance pay offer $\mathrm{S}$, $\mathrm{S}>0$. If the employee accepts this proposal, he will receive the respective amount $\mathrm{S}$, while the firm incurs costs $\mathrm{S}+\mathrm{K}^{\mathrm{s}}$. A rejection of the proposal will be tantamount to filing a labour court suit. The respective payoffs have been described above. They are assumed to be unaffected by the firm having made a severance pay offer because this proposal does not restrict the court's legal evaluation. In consequence, the firm's expected costs of a court procedure equal $\mathrm{C}+\mathrm{K}^{\mathrm{c}}$, whereas the employee's expected payoff is given by $\mathrm{C}-\mathrm{k}$.

Since 2004, the firm can also proceed in accordance with PaDA Sec. 1a. If the employee accepts the proposed payment, he will receive a monetary payment denoted by $\mathrm{Z}$. In addition, we allow for the notion of PaDA Sec. 1a establishing a standard or norm for severance payments by assuming that an employee obtains an additional, non-monetary payoff. This payoff may result from being treated fairly in accordance with a perceived entitlement - such as is laid down in PaDA Sec. 1a - or because an employee attaches positive value to not being at the firm's discretion with respect to the magnitude of the payment. The monetary equivalent of this additional payoff is given by $\mathrm{f}, \mathrm{f} \geq 0$. Since the legal requirements for a dismissal in accordance with PaDA Sec. 1a are less demanding than those that have to be observed in order to make a mutual agreement involving a payment $\mathrm{S}$ legally watertight, we normalise the firm's costs of legal advice if proceeding in line with PaDA Sec. 1a to zero. If the employee accepts the proposal of a contract termination in accordance with PaDA Sec. 1a, the firm's costs therefore amount to $\mathrm{Z}$, whereas the employee's payoff rises by $\mathrm{Z}+\mathrm{f}$. If the employee

\footnotetext{
12 Accordingly, we assume in our theoretical analysis that the PaDA applies. Otherwise, the regulations concerning PaDA Sec. 1a cannot form the legal basis for the firm's behaviour.
} 
rejects the firm's proposal, this choice is equivalent to filing a labour court suit with costs $\mathrm{k}$. As a direct consequence, the employee will no longer be entitled to the payment $\mathrm{Z}^{13}$ Once the offer $\mathrm{Z}$ is rejected, no further proposals or negotiations will be possible. Figure 1 depicts the feasible choices and resulting payoffs.

Figure 1: Sequence of Decisions

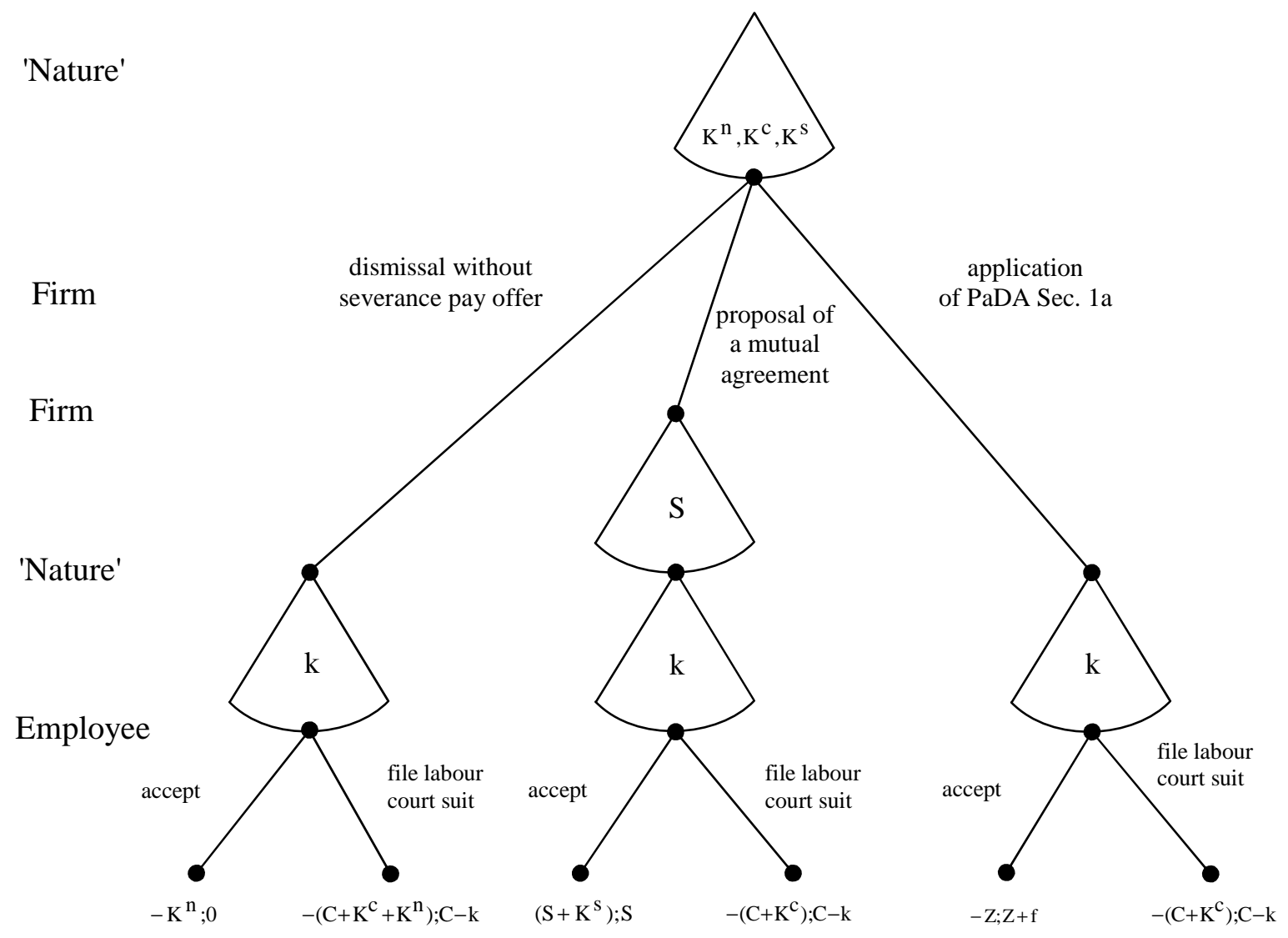

If the employee accepts a dismissal without a severance pay offer, his payoff will be zero. If he files a labour court suit, the expected value of his payoff equals $\mathrm{C}-\mathrm{k}$. In consequence, the employee will accept the dismissal if $\mathrm{k}>\mathrm{C}$. Given a uniform distribution of $\mathrm{k}$ on the interval $[0, \overline{\mathrm{k}}]$, the probability $\mathrm{p}$ of accepting the dismissal is given by:

$$
\mathrm{p}=\frac{\overline{\mathrm{k}}-\mathrm{C}}{\overline{\mathrm{k}}}=1-\frac{\mathrm{C}}{\overline{\mathrm{k}}}
$$

If the employee agrees to the firm's proposal of a mutual agreement including a severance payment $\mathrm{S}$, his payoff will amount to $\mathrm{S}$. The employee will accept the offer $\mathrm{S}$ if $\mathrm{S}>\mathrm{C}-\mathrm{k}$ holds. Hence, the probability $\mathrm{q}(\mathrm{S})$ of acceptance is given by:

\footnotetext{
${ }^{13}$ See, e.g., Preis (2004, pp. 74 f), Raab (2005, pp. 8 f), Hergenröder (2009, Sec. 1a para. 15 ff), Hesse (2007, para. 8), and Spilger (2009, pp. 248 f).
} 


$$
\mathrm{q}(\mathrm{S})=\frac{\overline{\mathrm{k}}-(\mathrm{C}-\mathrm{S})}{\overline{\mathrm{k}}}=1-\frac{\mathrm{C}-\mathrm{S}}{\overline{\mathrm{k}}}
$$

By analogy, the employee will consent to a proposed termination of the employment contract in accordance with PaDA Sec. 1a, if $\mathrm{Z}+\mathrm{f}>\mathrm{C}-\mathrm{k}$ applies. The probability of the firm's offer being accepted is denoted by $\mathrm{r}$ :

$$
\mathrm{r}=\frac{\overline{\mathrm{k}}-(\mathrm{C}-\mathrm{Z}-\mathrm{f})}{\overline{\mathrm{k}}}=1-\frac{\mathrm{C}-\mathrm{Z}-\mathrm{f}}{\overline{\mathrm{k}}}
$$

If the firm proposes a mutual agreement, it will choose the severance pay offer S such that the fall in expected costs due to the increase in the acceptance probability $q(S)$ just balances the additional costs owing to a higher payment if the offer is accepted. Therefore, the optimal offer $S^{*}$ results from the maximisation of $\Pi(S)$.

$$
\Pi(S)=-q(S)\left(S+K^{S}\right)-(1-q(S))\left(C+K^{c}\right)=-\left[1-\frac{C-S}{\bar{k}}\right]\left(S+K^{S}\right)-\left[\frac{C-S}{\bar{k}}\right]\left(C+K^{c}\right)
$$

In consequence, $S^{*}$ is given by:

$$
\mathrm{S}^{*}=\mathrm{C}+\frac{\mathrm{K}^{\mathrm{c}}-\mathrm{K}^{\mathrm{S}}-\overline{\mathrm{k}}}{2}
$$

Since the probability $q(S)$ cannot exceed unity, the optimal offer $S^{*}$ has to be less than the expected payment $\mathrm{C}$ resulting from a court's involvement (given an interior solution). The resulting restriction $\mathrm{K}^{\mathrm{c}}-\mathrm{K}^{\mathrm{S}}-\overline{\mathrm{k}}<0$ is assumed to hold. The expected payoff $\Pi\left(\mathrm{S}^{*}\right)$ can, using equations (4) and (5), be calculated as:

$$
\Pi\left(S^{*}\right)=-\mathrm{C}+\frac{\left(\mathrm{K}^{\mathrm{c}}+\mathrm{K}^{\mathrm{S}}-\overline{\mathrm{k}}\right)^{2}}{4 \overline{\mathrm{k}}}-\frac{\mathrm{K}^{\mathrm{c}} \mathrm{K}^{\mathrm{S}}}{\overline{\mathrm{k}}}<0
$$

The expected payoff of refraining from a severance pay offer and dismissing the employee without monetary compensation is given by $\Pi(0)=-p \cdot 0-(1-p)\left(C+K^{c}\right)-K^{n}$. Using equation (1), П(0) can be expressed as:

$$
\Pi(0)=-\frac{C\left(C+K^{c}\right)}{\bar{k}}-K^{n}<0
$$

Finally, the firm's expected payoff of proceeding in line with PaDA Sec. 1a equals $\Pi(Z)$ :

$$
\Pi(Z)=-\left[1-\frac{C-Z-f}{\bar{k}}\right] Z-\left[\frac{C-Z-f}{\bar{k}}\right]\left(C+K^{c}\right)=\frac{(C-Z-f)\left(Z-C-K^{c}\right)}{\bar{k}}-Z<0
$$


The probability $r$ of a severance pay offer based on PaDA Sec. 1a being accepted will only be less than unity if $\mathrm{C}>\mathrm{Z}+\mathrm{f}$ holds (cf. equation (3)). This implies that $\mathrm{Z}<\mathrm{C}$ and that the term $\mathrm{Z}-\mathrm{C}-\mathrm{K}^{\mathrm{c}}$ is negative.

\subsection{The Firm's Preferred Dismissal Procedure}

In the first step of the game, the firm decides whether it will attempt to dismiss the employee without a severance pay, propose a mutual agreement or proceed in accordance with PaDA Sec. 1a. To analyse this decision, we compare the firm's expected payoffs resulting from each choice and clarify that, depending on parameter values, each choice can be optimal. Accordingly, assuming the economy to be populated by a large number of firms characterised by different values of the costs $\mathrm{K}^{\mathrm{n}}, \mathrm{K}^{\mathrm{c}}$, and $\mathrm{K}^{\mathrm{s}}$, all types of dismissals will occur in equilibrium. We can summarise our findings in the following three Remarks:

\section{Remark 1: Mutual Agreement versus Outright Dismissal}

a) The firm is more likely to make an offer $\mathrm{S}^{*}$ instead of dismissing the employee without the odder of a payment, the higher the costs $\mathrm{K}^{\mathrm{n}}$ are.

b) If $\mathrm{K}^{\mathrm{s}}=\mathrm{K}^{\mathrm{c}}=\overline{\mathrm{k}}, \mathrm{K}^{\mathrm{n}}=0$, and the probability $\mathrm{p}$ of a dismissal without severance payment being accepted is greater than $\mathrm{p}^{\text {crit }}=1-\sqrt{3} / 2$, the firm will be better off as a result of refraining from making an offer instead of suggesting a mutual agreement including a payment $\mathrm{S}^{*}$.

Proof:

Let the difference between expected payoffs resulting from an offer $\mathrm{S}^{*}$ and those from no offer be denoted by $\Delta \Pi(\mathrm{S}, 0):=\Pi\left(\mathrm{S}^{*}\right)-\Pi(0)$. A positive difference indicates a higher payoff of offering $S^{*}$, since $\Pi\left(S^{*}\right), \Pi(0)<0$. The difference is given by:

$$
\Delta \Pi(\mathrm{S}, 0)=-\mathrm{C}+\frac{\left(\mathrm{K}^{\mathrm{c}}+\mathrm{K}^{\mathrm{S}}-\overline{\mathrm{k}}\right)^{2}}{4 \overline{\mathrm{k}}}-\frac{\mathrm{K}^{\mathrm{c}} \mathrm{K}^{\mathrm{S}}}{\overline{\mathrm{k}}}+\frac{\mathrm{C}\left(\mathrm{C}+\mathrm{K}^{\mathrm{c}}\right)}{\overline{\mathrm{k}}}+\mathrm{K}^{\mathrm{n}}
$$

Clearly, $\Delta \Pi(S, 0)$ is increasing in $\mathrm{K}^{\mathrm{n}}$. Substituting $\overline{\mathrm{k}}$ for $\mathrm{K}^{\mathrm{S}}$ and $\mathrm{K}^{\mathrm{c}}$ in $(9)$ and using the definition of $\mathrm{p}$ (cf. equation (1)), the payoff difference can be rewritten as:

$$
\left.\Delta \Pi(\mathrm{S}, 0)\right|_{\mathrm{K}^{\mathrm{S}}=\mathrm{K}^{\mathrm{C}}=\overline{\mathrm{k}}}=-\mathrm{C}+\frac{\overline{\mathrm{k}}}{4}-\overline{\mathrm{k}}+\frac{\mathrm{CC}}{\overline{\mathrm{k}}}+\mathrm{C}+\mathrm{K}^{\mathrm{n}}=-\frac{3 \overline{\mathrm{k}}}{4}+(1-\mathrm{p}) \mathrm{C}+\mathrm{K}^{\mathrm{n}}
$$




$$
=-\frac{\overline{\mathrm{k}}}{4}\left(3-4(1-\mathrm{p}) \frac{\mathrm{C}}{\overline{\mathrm{k}}}\right)+\mathrm{K}^{\mathrm{n}}=-\frac{\overline{\mathrm{k}}}{4}\left[3-(2(1-\mathrm{p}))^{2}\right]+\mathrm{K}^{\mathrm{n}}
$$

The expression in square brackets in equation (10) and, therefore, also $\Delta \Pi(\mathrm{S}, 0)$ is positive, given $\mathrm{K}^{\mathrm{n}}=0$, for any probability $\mathrm{p}$ greater than $\mathrm{p}^{\text {crit }}=1-\sqrt{3} / 2 \approx 0.134$.

Remark 1 implicitly clarifies the trade-off faced by a firm prior to the introduction of PaDA Sec. 1a. Part b) of Remark 1, for example, implies that an employee who can expect only a low expected payment $\mathrm{C}$ when going to court and, therefore, exhibits a high probability $\mathrm{p}$ of accepting a dismissal without a severance payment, is unlikely to be offered a mutual agreement including a payment $S^{*}$ by the firm. Therefore, Remark 1 captures the shadow of employment protection law in the determination of voluntary severance payments and a firm's choice of dismissal procedure.

Next, we will analyse whether the use of PaDA Sec. 1a can be beneficial for a firm, relative to a dismissal without a severance pay offer. The findings can be summarised in:

\section{Remark 2: Using PaDA Sec. 1a versus Outright Dismissal}

a) The firm is more likely to make an offer in accordance with PaDA Sec. 1a than to dismiss the employee without making any offer, the higher the employee's non-monetary gain $\mathrm{f}$ is. b) If $\mathrm{K}^{\mathrm{c}}=\overline{\mathrm{k}}$, the firm will be better off as a result of dismissing an employee in accordance with PaDA Sec. 1a than not making an offer.

Proof:

Let the difference between expected payoffs resulting from an offer $\mathrm{Z}$ and those from a dismissal without an offer be denoted by $\Delta \Pi(Z, 0):=\Pi(Z)-\Pi(0)$. This is given by:

$$
\begin{aligned}
\Delta \Pi(Z, 0) & =\frac{(\mathrm{C}-\mathrm{Z}-\mathrm{f})\left(\mathrm{Z}-\mathrm{C}-\mathrm{K}^{\mathrm{c}}\right)}{\overline{\mathrm{k}}}-\mathrm{Z}+\frac{\mathrm{C}\left(\mathrm{C}+\mathrm{K}^{\mathrm{c}}\right)}{\overline{\mathrm{k}}}+\mathrm{K}^{\mathrm{n}} \\
& =-\frac{(\mathrm{Z}+\mathrm{f})\left(\mathrm{Z}-\mathrm{C}-\mathrm{K}^{\mathrm{c}}\right)}{\overline{\mathrm{k}}}+\frac{\mathrm{CZ}}{\overline{\mathrm{k}}}-\mathrm{Z}+\mathrm{K}^{\mathrm{n}}
\end{aligned}
$$

Since $\left(\mathrm{Z}-\mathrm{C}-\mathrm{K}^{\mathrm{c}}\right)<0, \Delta \Pi(\mathrm{Z}, 0)$ is increasing in $\mathrm{f}$. Substituting $\overline{\mathrm{k}}$ for $\mathrm{K}^{\mathrm{c}}$ in $(11)$, setting $\mathrm{f}=0$, and using the definitions of $\mathrm{p}$ and $\mathrm{r}$ (cf. equations (1) and (3)), we obtain:

$$
\left.\Delta \Pi(\mathrm{Z}, 0)\right|_{\substack{\mathrm{K}^{\mathrm{c}}=\overline{\mathrm{k}} \\ \mathrm{f}=0}}=-\mathrm{Z} \frac{(\mathrm{Z}-\mathrm{C})}{\overline{\mathrm{k}}}+\mathrm{Z}+(1-\mathrm{p}) \mathrm{Z}-\mathrm{Z}+\mathrm{K}^{\mathrm{n}}=\mathrm{Z}(1-\mathrm{r}+1-\mathrm{p})+\mathrm{K}^{\mathrm{n}}>0
$$


Remark 2 shows that if the costs of a court procedure are sufficiently high, the firm will find a dismissal according to PaDA Sec. 1a cheaper than firing the employee without an initial severance pay offer.

Finally, we will compare the firm's expected payoff from offering a payment $S^{*}$ to obtain a mutual agreement with that of proceeding in accordance with PaDA Sec. 1a.

Remark 3: Mutual Agreement versus Using PaDA Sec. 1a

Assume $\mathrm{K}^{\mathrm{S}}=\mathrm{K}^{\mathrm{c}}=\overline{\mathrm{k}}$. A sufficient condition for the firm to benefit from proceeding in accordance with PaDA Sec. 1a instead of proposing a mutual agreement including a severance pay offer $S^{*}$ is that the probability $r$ of the firm's offer according to PaDA Sec. 1a being accepted does not fall below $25 \%$.

Proof:

Let the difference between expected payoffs resulting from an offer $\mathrm{Z}$ and those from the proposal of a mutual agreement be denoted by $\Delta \Pi(Z, S):=\Pi(Z)-\Pi\left(S^{*}\right)$. Using equation (3), $\Delta \Pi(Z, S)$ can be expressed as:

$$
\begin{aligned}
\Delta \Pi(Z, S) & =\frac{(C-Z-f)\left(Z-C-K^{c}\right)}{\bar{k}}-Z+C-\frac{\left(K^{c}+K^{S}-\bar{k}\right)^{2}}{4 \bar{k}}+\frac{K^{c} K^{S}}{\bar{k}} \\
& =-r(Z-C)-(1-r) K^{c}-\frac{\left(K^{c}+K^{S}-\bar{k}\right)^{2}}{4 \bar{k}}+\frac{K^{c} K^{S}}{\bar{k}}
\end{aligned}
$$

For $\mathrm{K}^{\mathrm{c}}=\mathrm{K}^{\mathrm{s}}=\overline{\mathrm{k}}$, we obtain:

$$
\Delta \Pi(\mathrm{Z}, \mathrm{S}){ }_{\mathrm{K}^{\mathrm{C}}=\mathrm{K}^{\mathrm{S}}=\overline{\mathrm{k}}}=-\mathrm{r}(\mathrm{Z}-\mathrm{C})+\overline{\mathrm{k}}\left(\mathrm{r}-\frac{1}{4}\right)
$$

Since $\mathrm{C}>\mathrm{Z}$ holds, given a positive probability 1 - $\mathrm{r}$ of a proposal in accordance with PaDA Sec. 1a being rejected, $\Delta \Pi(Z, S)$ will be unambiguously positive for $r \geq 0.25$.

For $\mathrm{K}^{\mathrm{S}}=0$, a sufficiently high value of $\mathrm{K}^{\mathrm{c}}(<\overline{\mathrm{k}})$, that is, of the costs of a court procedure, ensures that $\Delta \Pi(Z, S)<0$ and, thus, that the firm prefers to offer a payment $S^{*}$ (instead of $Z>$ $\left.\mathrm{S}^{*}\right)$, because this reduces the costs of a payment sufficiently to overcompensate for the fall in the acceptance probability from $r$ to $q$ (given $f=0$, cf. equations (1) and (3)). Accordingly, 
Remark 3 has the same flavour as Remark 2. Firms may - but need not - find it profitable to use PaDA Sec. 1a instead of the alternative, i.e. voluntarily offering a payment $S^{*} .{ }^{14}$

Remarks 1 to 3 show that there are values of $\mathrm{K}^{\mathrm{n}}, \mathrm{K}^{\mathrm{c}}$, and $\mathrm{K}^{\mathrm{S}}$ characterising the firm and of $\overline{\mathrm{k}}$ and $\mathrm{C}$ relating to the employee which ensure that a firm may find either of the three procedures to terminate an employment relationship the least costly. The intuition for the relevance of PaDA Sec. 1a is the following. First, using the procedure lowers the firm's administrative costs, relative to a mutual agreement or a court procedure (by assumption). Second, if the employee accepts the offer $\mathrm{Z}$, the payment will be less than that resulting from a court's involvement. Third, for a given payment, the acceptance probability q exceeds the probability $r$ because of the gain $\mathrm{f}$. However, proceeding in accordance with PaDA Sec. 1a also entails two disadvantages. By offering $\mathrm{Z}$, firms forego the possibility of avoiding a payment, if the employee would have accepted a dismissal without a severance pay offer. In addition, $\mathrm{Z}$ will generally diverge from the 'optimal' offer $\mathrm{S}^{*}$. The firm will make use of PaDA Sec. 1a if the disadvantages are outweighted by the aforementioned cost-reducing effects.

\subsection{Non-controversial Payments and Expected Severance Payments}

In our data we have information on whether a dismissed employee claims to have received a severance payment as a result of a mutual agreement with the employer. We interpret such a statement as tantamount to the information that the severance payment did not result from a labour court suit, because filing a suit implies rejecting the conditions attached to the firm's dismissal decision. Furthermore, employees can state that they experienced a layoff. Severance payments in such an event may also occur without a court being involved. In our theoretical model, such non-controversial payments will, prior to the introduction of PaDA Sec. 1a, be given by $\mathrm{S}^{*}$. Since 2004 , a non-controversial payment can arise either because the firm proposes a mutual agreement including a payment $S^{*}$, which the employee accepts, or because the firm proposes a termination of the employment contract in line with PaDA Sec. 1a, which the employee does not object to. In this case, the severance payment amounts to $\mathrm{Z}$. Since the optimal payment $\mathrm{S}^{*}$ is unaffected by the introduction of PaDA Sec. 1a (cf. equation (5)), the expected level of non-controversial payments will fall (rise) with the introduction of PaDA Sec. $1 \mathrm{a}$ if $\mathrm{S}^{*}>(<) \mathrm{Z}$.

\footnotetext{
${ }^{14}$ Note that if, in contrast to our assumption, the costs $\mathrm{K}^{\mathrm{S}}$ arose also if the offer of a mutual agreement were declined, the condition for the firm to prefer PaDA Sec. 1a relative to a mutual agreement would more likely to hold than in the present set-up.
} 
The assumption that the payment $\mathrm{Z}$ defined by PaDA Sec. 1a is less than the severance payments $S^{*}$ has sometimes been interpreted as being equivalent to a loss of workers. However, since not only the level of payments may change - from $\mathrm{C}$ or $\mathrm{S}^{*}$ to $\mathrm{Z}$ - but also the probability of obtaining such payments, a more adequate measure of the change in the worker's wellbeing is the expected severance payment. Let A denote the probability that proposing a mutual agreement generates a higher expected payoff for the firm than dismissing the employee without severance pay offer, i.e., that $\Delta \Pi(S, 0)>0$. The expected or average severance payment $\mathrm{Pb}$ of a dismissed employee, prior to the introduction of PaDA Sec. 1a, can be expressed as:

$$
\mathrm{P}^{\mathrm{b}}=\mathrm{A}\left[\mathrm{q}\left(\mathrm{S}^{*}\right) \mathrm{S}^{*}+\left(1-\mathrm{q}\left(\mathrm{S}^{*}\right)\right) \mathrm{C}\right]+(1-\mathrm{A})(1-\mathrm{p}) \mathrm{C}
$$

Let the probability that the firm offers a payment $\mathrm{Z}$ - subsequent to the introduction of PaDA Sec. 1a - be given by B. Put differently, B represents the probability that $\Delta \Pi(\mathrm{Z}, \mathrm{S})$ and $\Delta \Pi(\mathrm{Z}, 0)$ are positive. Because the optimal severance pay offer $\mathrm{S}^{*}$ is unaffected, the probability A that $\Delta \Pi(S, 0)>0$ holds is independent of the existence of PaDA Sec. 1a. In addition, the expected payment $\mathrm{C}$ resulting from filing a suit remains unchanged, since the legal evaluation of a case is not altered. In consequence, the expected or average severance payment $\mathrm{P}^{\mathrm{S}}$ of a dismissed employee since the introduction of PaDA Sec. 1a equals:

$$
\mathrm{P}^{\mathrm{S}}=\mathrm{B}[\mathrm{rZ}+(1-\mathrm{r}) \mathrm{C}]+(1-\mathrm{B}) \mathrm{P}^{\mathrm{b}}
$$

The difference in expected severance payments due to the introduction of PaDA Sec. 1a is given by $\mathrm{P}^{\mathrm{s}}-\mathrm{P}^{\mathrm{b}}$, or in other terms, determined by:

$$
\begin{aligned}
r Z+(1-r) C- & A\left[q\left(S^{*}\right) S^{*}+\left(1-q\left(S^{*}\right)\right) C\right]-(1-A)(1-p) C \\
= & r Z-A q\left(S^{*}\right) S^{*}+C[p(1-A)+A q-r] \\
= & r Z+(p(1-A)-r) C-A q \underbrace{\left(S^{*}\right) \frac{K^{c}-K^{S}-\bar{k}}{2}}_{<0}
\end{aligned}
$$

This expression may be positive or negative, suggesting that dismissed employees may lose or gain due to the introduction of PADA Sec. 1a. For an example indicating that employees may gain, note that the last term in the last line of equation (17) is negative and deducted, given a probability $\mathrm{q}\left(\mathrm{S}^{*}\right)<1$ (cf. equations (2) and (5)). $\mathrm{PS}^{\mathrm{S}}>\mathrm{P}^{\mathrm{b}}$ will then unambiguously apply if $\mathrm{rZ}$ $+(\mathrm{p}(1-\mathrm{A})-\mathrm{r}) \mathrm{C}>0$ holds. However, assuming $\mathrm{Z}=\mathrm{S}^{*}=\mathrm{C} / 2$ and $\mathrm{f}=0$ implies that $\mathrm{r}=\mathrm{q}$. 
Making use of $r=p-Z / \bar{k}$ and substituting in the second line of equation (17) for $S^{*}, C, p$ and $r$, we can show that the sign of equation (17) is determined by $(1-\mathrm{Z} / \overline{\mathrm{k}})$, which may be positive or negative. Accordingly, whether a dismissed worker has lost or gained owing to the new section in the PaDA is an empirical issue. We summarise our findings in:

\section{Proposition 1}

Assume that some firms dismiss workers in accordance with PaDA Sec. 1a. Noncontroversial severance payments, i.e. those resulting without a court's involvement, will decline on average with the introduction of PaDA Sec. 1a if $\mathrm{S}^{*}>$ Z. Average observed severance payments in the case of individual dismissals may rise or fall due to the introduction of PaDA Sec. 1a.

In summary, the model casts doubts on the assertions often found in legal interpretations that PaDA Sec. 1a will either have no impact or will clearly make dismissed workers better off as a result of the new section establishing a lower boundary for severance payments.

\section{Data and Empirical Strategy}

\subsection{Data}

Our data stems from the German Socio-Economic panel (SOEP) which is a representative longitudinal survey of the resident population in Germany conducted since 1984 (cf. Wagner, Frick and Schupp (2007) or http://www.diw.de/de/soep). We use data from the survey years 2000 to 2007 to extract a sample of observed terminations of employment contracts in West Germany from January 2001 to December 2006. This allows us to set up a symmetric threeyear time period around the date when PaDA Sec. 1a was introduced on 1 January, 2004. Moreover, we restrict ourselves to terminations in firms with at least 5 employees because the PaDA was never applicable if there had been fewer employees. We include observed contract terminations due to a closure of the firm or plant, a layoff and a mutual agreement. In all these events, PaDA Sec. 1a may have affected the level of severance payments. However, our data provides no information on whether a labour suit was filed or not. Those civil servants which can effectively not be dismissed ('Beamte'), apprentices, and employees with temporary contracts or going into retirement are excluded from our data. Additionally, we require all respondents to be over the age of 17 and no older than 65 years, and to have either a full- or part-time job. Given the panel structure of the SOEP, it is feasible to link the information on employment terminations with information regarding individual characteristics (such as the 
type of job or tenure) and firm features. Finally, we use weighting factors provided with the SOEP, which account for the sample design of the different sub-samples of the SOEP as well as for panel attrition in all empirical analyses (cf. Pannenberg et al. 2005).

Information on severance payments comes from a question on the prevalence and amount of such payments. For $\mathrm{N}=244\left(\mathrm{~N}_{\text {before }} 2004=135 ; \mathrm{N}_{\text {since }} 2004=109\right)$ employees with job terminations we have valid observations on severance payments. The average real severance pay equals $€ 13,841$ (median $=€ 8,084$ ). ${ }^{15}$ In our empirical work we additionally use some variables based on the information provided in the last survey prior to the termination of the employment contract. These variables either reflect legal regulations or have been found in other studies to determine severance payments in Germany (cf. Section 2.1 above and, e.g., Goerke and Pannenberg 2010a). They include tenure, the interaction of age and tenure in accordance with the limits stipulated by the PaDA [age in years $\geq 50$ (55) and tenure $\geq 15$ (20) years], dummy variables for gender, the existence of alimony duties and for officially recognised disability status, measures for firm size $(5-19,20-199,200-1999,2000$ or more employees), occupational status (blue collar/ white collar) and the type of job termination (firm or plant closure, layoff, mutual agreement).

\subsection{Empirical Strategy}

To estimate the effect of the introduction of PaDA Sec. 1a on severance payments, we use a difference-in-differences-strategy (DID). As described above, WCA Sec. 112(a) stipulates the obligation to set up a social plan in the case of a mass dismissal. Such social plans typically contain generous and detailed guidelines on severance payments and employers cannot circumvent them by using PaDA Sec. 1a. Hence, PaDA Sec. 1a should have had no direct impact on severance payments based on social plans. We exploit this hypothesis and use observed severance payments in those cases of collective dismissals in which WCA Sec. 112 is applicable as a control group in our DID-specifications.

In our data we can distinguish between three types of job terminations: those due to a (a) closure of the firm or plant; (b) layoff; (c) mutual agreement. The category "closure of the firm or plant" clearly includes collective dismissals. However, it is essential for the validity of our empirical strategy that the control group consists only of such employees who are collectively dismissed in a firm with 20 or more employees in which a works council exists. Unfortunately, information on the existence of a works council is only available for the SOEP

\footnotetext{
${ }^{15}$ The CPI is used to calculate real severance payments (base year 2000).
} 
survey years 2001 and 2006. To construct such a works council indicator for every year from 2001 to 2006 in our sample, we use observations from the years 2001 and 2006 to estimate the parameters of a probit model of the likelihood of a works council existing in the particular firm. ${ }^{16}$ Subsequently, we use these parameter estimates to calculate "out of sample" predictions, as well as an estimated dummy variable, "existence of a works council", for the years 2002 to 2005 , for which information on the existence of a works council is missing. ${ }^{17}$ In our sample, the resulting estimated fraction of employees working in firms with a works council for the years 2001 to 2006 amounts to $47 \%$. This number is almost identical to the estimate of $48 \%$ provided by Ellguth and Kohaut (2010) for the same period based on representative firm panel data for West Germany.

In sum, our control group consists of those respondents receiving a severance payment for whom, first, we observe a job termination due to a "closure of the firm" and who, second, worked in a firm with 20 or more employees in which a works council existed, as can be observed for the years 2001 and 2006 and (partly) estimated for the period 2002 to 2005. All other observed job terminations due to the closure of a firm are (re-) classified as layoffs. Severance payments in the case of layoffs and mutual agreements to terminate an employment contract may be affected by the introduction of PaDA Sec. 1a and, therefore, define two separate treatment groups.

To assess the (short-run) effect of the introduction of PaDA Sec. 1a on the amount of severance pay, we use the following DID-regression specification:

$$
\begin{aligned}
\mathrm{y}_{\mathrm{it}}=\alpha_{0} & +\beta_{1}(\text { mutual agreement } * \text { since } 2004)+\beta_{2}(\text { individual layoff } * \text { since } 2004) \\
& +\beta_{3}(\text { since } 2004)+\beta_{4}(\text { mutual agreement })+\beta_{5}(\text { individual layoff }) \\
& +\mathrm{x}_{\mathrm{it}} \gamma+\varepsilon_{\mathrm{it}}
\end{aligned}
$$

where $y_{i t}$ represents the $\log$ of real severance payments; $\beta_{1}, \beta_{2}$ are the key parameters of interest, indicating a causal effect of the introduction of PaDA Sec.1 on severance payments for dismissed employees who obtained the payments due to a mutual agreement, or because of a layoff; and $\mathrm{x}_{\mathrm{it}}(\gamma)$ is a vector of control variables (parameters).

The key identifying assumption of equation (18) is that severance payment trends would be the same for all groups in the absence of treatment, i.e. if PaDA Sec. 1a had not been

\footnotetext{
${ }^{16}$ The estimated parameters of the probit model are presented in Table A1 in the Appendix.

${ }^{17}$ For the years 2002 to 2005 the dummy variable "existence of a works council" equals 1 if the predicted individual probability of working in a firm in which a works council exists is greater than or equal to the respective unconditional (predicted) fraction.
} 
introduced. ${ }^{18}$ This implies that there are no other events that occurred around the year 2004, when the PaDA was altered, that affected treatment and control groups differently. Importantly, the WCA was not amended after 2002. As described above, two policy changes took place during the period under consideration: namely, changes in the taxation of severance pay and a reform of the unemployment benefit system. In our checks of robustness below we analyse their possible impact by allowing for further interaction terms in our DIDspecifications. Furthermore, we investigate whether there was an effect resulting from the change in the applicability of the PaDA that exempted most employees in firms with five or more but less than 10 employees.

\section{Results}

Figure 2 depicts the development of average real severance pay over time for employees characterised by different types of job terminations. The figure indicates a comprehensive and remarkable increase in the level of payments since 2004. Respondents who experienced a layoff $(+88 \%)$ or signed a mutual agreement $(+62 \%)$ exhibited a more pronounced rise than employees belonging to the control group, which encompasses those people with job losses resulting from collective dismissals $(+42 \%)$. Note, that these results might be (partly) driven by composition effects. Therefore, it remains to be seen whether the regression-adjusted results from the DID-specification confirm the descriptive evidence.

\section{- Figure 2: Average Amount of Real Severance Pay -}

Table 1 displays parameter estimates of the DID-specification of equation (18). The estimated parameters of the two interactions we are primarily interested in, namely since_04*mutual agreement and since_04*individual layoff, are both significantly negative. They indicate that both groups of dismissed employees, who may have been confronted with a severance pay offer in accordance with PaDA Sec. 1a, have seen notable reductions in the level of severance payments since 2004, relative to the comparison group of respondents who experienced a collective dismissal. Furthermore, the estimated parameter of the time dummy since_04 indicates that severance payments have increased since 2004, which is in line with the descriptive evidence displayed in Figure 2 and also with estimates by Jahn (2009).

- Table 1: DID-Estimates of Severance Pay and PaDA Sec. 1a -

\footnotetext{
${ }^{18}$ Blundell and Costas-Dias (2009), for example, provide a detailed discussion of the key assumptions of the DID-approach.
} 
The parameter estimates for the set of control variables are consistent with evidence previously obtained (see, e.g., Grund (2006), Jahn (2005, 2009), and Goerke and Pannenberg (2009, 2010a). In particular, we find a positive correlation with the last wage, tenure, and the existence of alimony obligations, whereas gender has no significant impact. Employees belonging to the two age-tenure groups defined by the PaDA (i.e. those above 50 (55) years of age and having a tenure of more than 15 (20) years), experience a decline in the level of payments, relative to the control group. Furthermore, it is noteworthy that the elasticity of severance pay with respect to the last wage is significantly greater than unity and that the impact of tenure on severance pay is non-linear.

As mentioned above, two potentially relevant policy changes took place around the time when PaDA Sec. 1a was introduced. The first was a change in taxation. Income tax exemption thresholds for severance pay were reduced by larger absolute amounts for the two age-tenure groups (age $\geq 50$ years $\&$ tenure $\geq 15$ years and age $\geq 55$ years $\&$ tenure $\geq 20$ years) than for the majority of employees and were completely abolished for all employees at the beginning of 2006. Exploiting a former increase in the taxation of severance pay in 1999, Goerke and Pannenberg (2009) show that it (a) lowered the probability of receiving severance pay and (b) tended to reduce the level of severance payments for the two age-tenure groups entitled to higher tax exemption levels as well as to higher upper limits of severance payments according to the PaDA (age $\geq 50$ years $\&$ tenure $\geq 15$ years and age $\geq 55$ years $\&$ tenure $\geq 20$ years). To tackle the question of whether our main results are influenced by the change in taxation, we add the following two triple interaction terms to equation (18): since_04*mutual agreement $*[($ age $\geq 50$ years \& tenure $\geq 15$ years $)$ or (age $\geq 55$ years \& tenure $\geq 20$ years) $]$ and since_04*individual layoff* $[($ age $\geq 50$ years \& tenure $\geq 15$ years) or (age $\geq 55$ years \& tenure $\geq 20$ years)]. The results displayed in the upper part of Table 2 show that the estimated parameters for the two interactions of main interest remain significantly negative, while the additionally estimated parameters of the two triple interactions are not significantly different from zero. Therefore, we continue to find evidence for a relative drop in severance pay for the two groups of employees who may have been affected by PaDA Sec. 1a. ${ }^{19}$

- Table 2: Checks of Robustness -

\footnotetext{
19 Table 2 contains only information on the estimated parameters for variables capturing the impact of PaDA Sec.1a. The findings for the further covariates resemble those displayed in Table 1 and are available upon request from the authors.
} 
A second concern relates to the reform of the unemployment benefit system in Germany, which became effective in February 2006 and significantly reduced the entitlement period for older workers. There is evidence of an anticipation effect because entries into unemployment peaked during the months preceding the reform (cf. Dlugosz, Stephan and Wilke 2009). This anticipation effect might influence our results due to its potential impact on the outcome of a bargain between the firm and employee regarding severance pay. In terms of our theoretical model, the legal change could violate the assumption that income subsequent to a dismissal is determined only by severance pay. In order to cater for the possible effect of the alteration of the unemployment benefit system, we enhance our baseline specification equation (18) by adding two triple interaction terms, namely since_04*mutual agreement $*$ (age $\geq 45$ years) and since_04*individual layoff*(age $\geq 45$ years), as well as the main effect age $\geq 45$ years. The reason is that workers below the age of 45 were not affected by the 2006 change of the unemployment benefit entitlement period. Moreover, they are less likely to become long-term unemployed than workers of higher age and, thus, unlikely to be affected by the introduction of Arbeitslosengeld II directly. Finally, workers less than 45 years of age belong to the group of income tax payers who experienced the smallest increase in the taxation of severance pay.

The estimated parameters in the lower part of Table 2 indicate that the reduction in severance pay since 2004 is less pronounced for older workers having experienced a layoff, but that there are no heterogeneous effects with respect to the group with mutual agreements. Moreover, the estimated parameters of the two variables since_04*mutual agreement and since_04*individual layoff we are mainly interested in, are again significantly negative. ${ }^{20}$

As mentioned in Section 2, the amendments to the PaDA in 2004 included not only the addition of Sec. 1a but also an increase in the threshold of the number of employees who have to work in the firm in order to make the PaDA applicable (Sec. $23 \mathrm{PaDA}$ ). In particular, employees in firms with more than five but not more than ten employees were no longer covered by the regulations of the PaDA, unless they had already been working in that firm in 2003. As a further check of robustness, it would be desirable to re-run our empirical specifications based on a sample of employees who worked in firms in which the PaDA had always been applicable, that is, those with a staff of more than 10 employees. However, sufficiently detailed firm size information has only been available in the SOEP since 2004. Therefore, we have restricted our sample to dismissed employees who obtained a severance

\footnotetext{
${ }^{20}$ The estimated parameter of the main effect, age $\geq 45$, is not significantly different from zero (see below). Note that age will have no significant impact either if we include a linear age term in any of the empirical specifications used in the paper.
} 
payment and worked in a firm with twenty or more employees, since this firm size variable is on hand for the entire observation period. Our findings, particularly for the interaction terms of main interest, were virtually unchanged when limiting the sample in this manner.

In sum, we find across all specifications that respondents with contract terminations due to a mutual agreement or a layoff experienced a notable reduction in the level of severance pay after the reform of the PaDA, relative to the payments obtained by the respondents belonging to the control group. Furthermore, before 2004 severance pay factors characterising payments in the case of job losses due to layoffs or mutual agreements were generally above 0.5 , the value defined by PaDA Sec. 1a. ${ }^{21}$ Severance payments resulting from mutual agreements clearly constitute non-controversial payments. Moreover, also in the case of layoffs agreements about severance pay without a court's involvement are of great relevance. Therefore, $\mathrm{S}^{*}>\mathrm{Z}$ is likely to hold and the results reported are in line with Proposition 1 of our theoretical model with respect to non-controversial severance payments.

Moreover, we find in our data that the probability of obtaining a severance payment when experiencing a layoff or due to a mutual agreement is virtually the same for the period prior to 2004 as for the three years following the introduction of PaDA Sec. 1a. Therefore, the average level of severance pay a dismissed employee obtained in the case of an individual dismissal did not change because of a variation in the probabilities of obtaining the respective payments. We can, therefore, conclude that the expected amount of severance payments is likely to have fallen since 2004 for those workers who lost their job because of either a mutual agreement to terminate the contract or a layoff, relative to the expected payoff of dismissed workers not directly affected by PaDA Sec. 1a. In terms of our theoretical model, this interpretation implies that $\mathrm{P}^{\mathrm{b}}>\mathrm{P}^{\mathrm{s}}$. In consequence, and in contrast to the fears of some legal scholars and also economists, the introduction of PaDA Sec. 1a has not been beneficial for dismissed employees.

\section{Summary}

Before and also subsequent to the introduction of PaDA Sec. 1a it was claimed by a large number of primarily legal scholars that the new section in the law would have no effect on the level of employment protection legislation in Germany in general and on severance payments in particular. The argument put forward was that the outcome of the new regulation could

\footnotetext{
${ }^{21}$ See, for example, Jahn (2005) and Grund (2006). In our data we calculate severance pay factors from 2001 to 2003 of 0.68 (0.52) for mutual agreements (layoffs).
} 
already have been obtained prior to the amendment. Alternatively, some experts argued that the level of severance pay defined by PaDA Sec. 1a constituted a lower threshold, while the German Trade Union Federation feared a deterioration of the employees' position. We show in a theoretical model that firms are likely to use the new procedure to dismiss workers, given that dismissal costs and the employees' willingness to accept a dismissal are affected by the new section in the PaDA. Furthermore, the theoretical model illustrates that severance payments obtained without a court's involvement and also average payments may decline with the introduction of the law. In our empirical analysis we use data from the Socio-Economic Panel for West Germany for a three-year period extending prior to and following the law's amendment in 2004. We show that severance payments obtained by dismissed employees who may have been affected by the new regulation declined, relative to payments obtained by a control group, whose payments resulted from a social plan to which PaDA Sec. 1a is not applicable. We therefore conclude that the change in the PaDA made employees worse off who may have obtained a severance payment in accordance with the new section of the PaDA, relative to those not directly affected by the legal change. Although variations in severance payments only provide indirect evidence, our findings suggest that the claim was unfounded that the new procedure will not be used. Rather, the fear articulated by the Confederation of German Trade Unions that employees would suffer from the law's amendment appears to be justified. 
Figure 2: Average Amount of Real Severance Pay

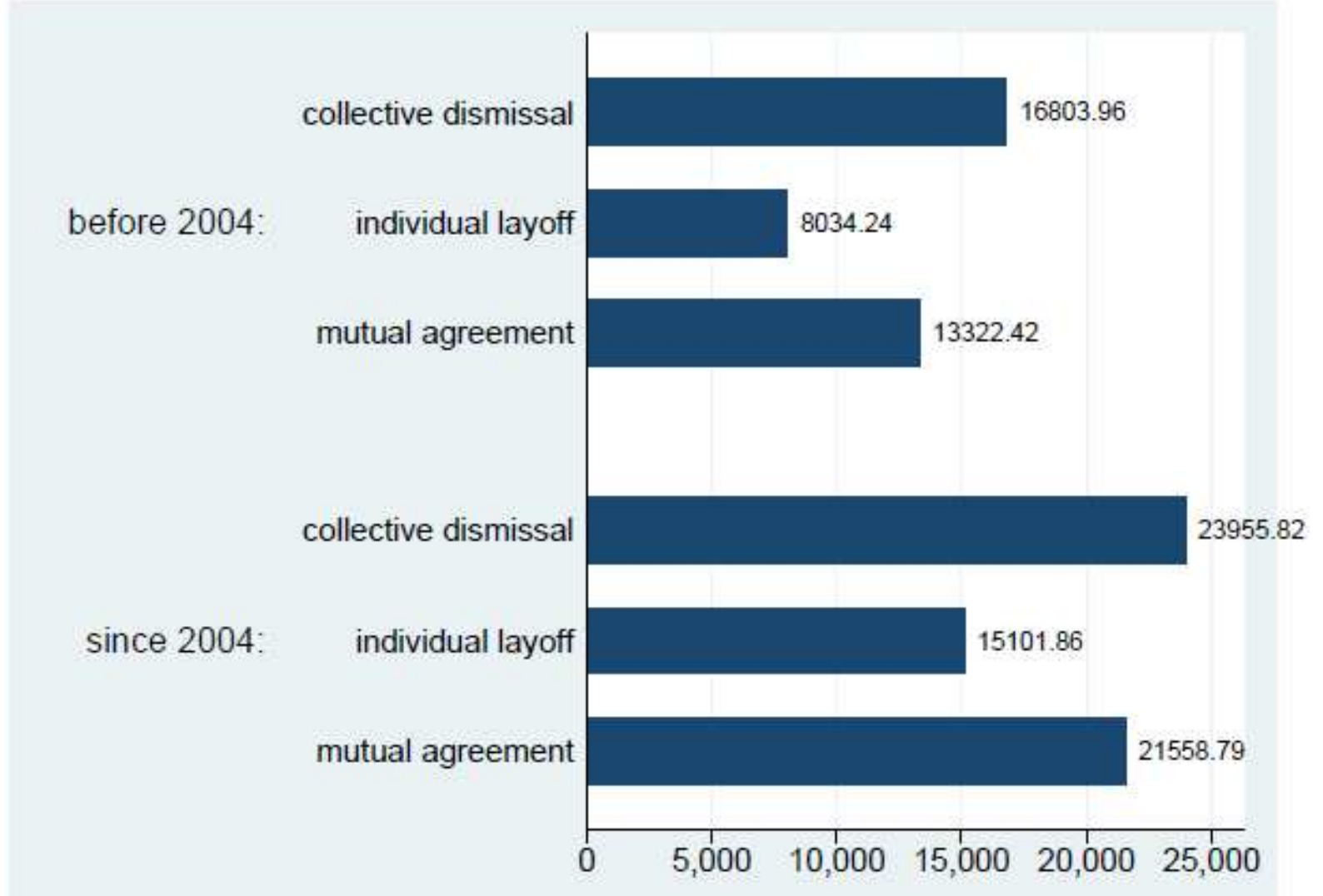

SOEP 2001-2006. N = 244. Survey weights are used. 
Table 1: DID-Estimates of Severance Pay and PaDA Sec. 1a

\begin{tabular}{|c|c|c|}
\hline Variable & Coefficient & Standard Error \\
\hline Since_04 $*$ mutual agreement & $-0.769 * *$ & 0.238 \\
\hline Since_04 $*$ individual layoff & $-0.439 *$ & 0.219 \\
\hline Individual layoff & 0.137 & 0.164 \\
\hline Mutual agreement & $0.324 *$ & 0.149 \\
\hline Since_04 & $0.483 *$ & 0.189 \\
\hline Last real monthly wage (log) & $1.264 * *$ & 0.118 \\
\hline Tenure of last job & $0.170 * *$ & 0.018 \\
\hline Tenure of last job squared & $-0.003 * *$ & 0.001 \\
\hline Male & -0.135 & 0.104 \\
\hline Alimony & $0.218^{+}$ & 0.112 \\
\hline Firm size: $20 \leq X<200$ employees & -0.080 & 0.132 \\
\hline Firm size: $200 \leq X<2000$ employees & 0.167 & 0.133 \\
\hline Firm size: $X \geq 2000$ employees & 0.090 & 0.120 \\
\hline White collar worker & 0.063 & 0.120 \\
\hline Handicap & 0.251 & 0.152 \\
\hline Age $\geq 50$ years $\&$ tenure $\geq 15$ years & $-0.913 * *$ & 0.170 \\
\hline Age $\geq 55$ years $\&$ tenure $\geq 20$ years & $-0.538 *$ & 0.233 \\
\hline Constant & $-2.373 * *$ & 0.917 \\
\hline Wald_X (df) & \multicolumn{2}{|c|}{$736.1 * *(22)$} \\
\hline $\mathrm{R}^{2}$ & \multicolumn{2}{|c|}{0.77} \\
\hline Number of observations & \multicolumn{2}{|c|}{244} \\
\hline
\end{tabular}

Source: SOEP 2000-2007. Survey weights are used.

OLS: Dependent variable: $(\log )$ real amount of severance pay.

Significance level: ** (0.01), * (0.05), + (0.10).

Industry dummy variables included. 
Table 2: Checks of Robustness

\begin{tabular}{|c|c|c|}
\hline Variable & Coefficient & Standard Error \\
\hline \multicolumn{3}{|c|}{ Controlling for additional tax/tenure group interactions } \\
\hline Since_04 * mutual agreement & $-0.595 * *$ & 0.221 \\
\hline Since_04 $*$ individual layoff & $-0.499 *$ & 0.223 \\
\hline Since_04 $*$ mutual agreement $*$ & -0.460 & 0.296 \\
\hline \multicolumn{3}{|l|}{$[($ age $\geq 50 \&$ tenure $\geq 15)$ or $($ age $\geq 55 \&$ tenure $\geq 20)]$} \\
\hline Since_04 $*$ individual layoff $*$ & 0.319 & 0.244 \\
\hline \multicolumn{3}{|l|}{$[($ age $\geq 50 \&$ tenure $\geq 15)$ or $($ age $\geq 55 \&$ tenure $\geq 20)]$} \\
\hline Mutual agreement & $0.333^{*}$ & 0.149 \\
\hline Individual layoff & 0.169 & 0.163 \\
\hline Age $\geq 50$ years $\&$ tenure $\geq 15$ years & $-0.944 * *$ & 0.170 \\
\hline Age $\geq 55$ years $\&$ tenure $\geq 20$ years & $-0.525^{*}$ & 0.233 \\
\hline Since_04 & $0.489 *$ & 0.188 \\
\hline Wald_X (df) & \multicolumn{2}{|c|}{$840.0 * *(24)$} \\
\hline $\mathrm{R}^{2}$ & \multicolumn{2}{|c|}{0.78} \\
\hline Number of observations & \multicolumn{2}{|r|}{244} \\
\hline \multicolumn{3}{|c|}{ Controlling for additional age group interactions } \\
\hline Since_04 $*$ mutual agreement & $-0.515^{*}$ & 0.258 \\
\hline Since_04 $*$ individual layoff & $-0.595^{*}$ & 0.240 \\
\hline Since_04 $*$ mutual agreement $*$ (age $\geq 45$ years) & -0.214 & 0.250 \\
\hline Since_04 $*$ individual layoff $*$ (age $\geq 45$ years $)$ & $0.352+$ & 0.200 \\
\hline Mutual agreement & $0.254+$ & 0.153 \\
\hline Individual layoff & 0.126 & 0.165 \\
\hline Age $\geq 45$ years & -0.212 & 0.141 \\
\hline Since_04 & $0.467 *$ & 0.196 \\
\hline Wald_X (df) & \multicolumn{2}{|c|}{$743.75 * *(25)$} \\
\hline $\mathrm{R}^{2}$ & \multicolumn{2}{|c|}{0.78} \\
\hline Number of observations & \multicolumn{2}{|c|}{244} \\
\hline
\end{tabular}

Source: SOEP 2000-2007. Survey weights are used.

OLS: Dependent variable: $(\log )$ real amount of severance pay.

Significance level: ** $(0.01), *(0.05),+(0.10)$.

Industry dummy variables included.

Further control variables: see Table 1. 


\section{References}

Bader, Peter (2004), Das Gesetz zu Reformen am Arbeitsmarkt: Neues im Kündigungsschutzgesetz und im Befristungsrecht, Neue Zeitschrift für Arbeitsrecht, Issue 2, 65-76.

Bauer, Jobst-Hubertus and Steffen Krieger (2004), Neuer Abfindungsanspruch - 1a daneben, Neue Zeitschrift für Arbeitsrecht, Issue 2, 77-79.

Bertola, Guiseppe, Boeri, Tito und Sandrine Cazes (1999), Employment Protection and Labour Market Adjustment in OECD Countries: Evolving Institutions and Variable Enforcement, ILO Employment and Training Papers No. 48.

Blundell, Richard and Monica Costa-Dias (2009), Alternative Approaches to Evaluation in Empirical Microeconomics, Journal of Human Resources 44(3), 565-640.

Däubler, Wolfgang (2004), Neues zur betriebsbedingten Kündigung, Neue Zeitschrift für Arbeitsrecht, Issue 4, 177-184.

Däubler, Wolfgang, Kittner, Michael and Thomas Klebe (eds.) (2008), Betriebsverfassungsgesetz, $11^{\text {th. }}$ ed., Bund-Verlag.

Deutscher Bundestag (2003a), Entwurf eines Gesetzes zu Reformen am Arbeitsmarkt, Drucksache 15/1204, 24.6.2003.

Deutscher Bundestag (2003b), Ausschuss für Wirtschaft und Arbeit, Materialien für die öffentliche Anhörung von Sachverständigen, Ausschussdrucksache 15(9)560, 22.8.2003.

Dlugosz, Stephan, Stephan, Gesine and Ralf A. Wilke (2009), Fixing the Leak: Unemployment Incidence before and after the 2006 Reform of Unemployment Benefits in Germany, IAB Discussion Paper 25/2009.

Ellguth, Peter and Susanne Kohaut (2010), Tarifbindung und betriebliche Interessenvertretung - Aktuelle Ergebnisse aus dem IAB-Betriebspanel 2009, WSIMitteilungen 4, 204-210.

Fabricius, Fritz (ed.) (2010), Betriebsverfassungsgesetz, Vol. 2, $9^{\text {th. }}$ ed., Luchterhand.

Goerke, Laszlo and Markus Pannenberg (2009), The Effects of Income Taxation on Severance Pay, Labour Economics 16(1), 107-118.

Goerke, Laszlo and Markus Pannenberg (2010a), An Economic Analysis of Dismissal Legislation: Determinants of Severance Pay in West Germany, International Review of Law and Economics 30, 71-85.

Goerke, Laszlo and Markus Pannenberg (2010b), Ist §1a KSchG ein „Nullum“? Eine Analyse der Veränderung in der Verteilung der Abfindungsfaktoren in Westdeutschland, Die Betriebswirtschaft (forthcoming).

Grund, Christian (2006), Severance Payments for Dismissed Employees in Germany, European Journal of Law and Economics 22, 49-71.

Hardege, Stefan and Edgar Schmitz (2008), Die Kosten des Kündigungsschutzes in Deutschland, Deutscher Instituts-Verlag: Köln.

Hergenröder, Curt W. (2009), Kündigungsschutzgesetz, in: Münchner Kommentar zum Bürgerlichen Gesetzbuch, $5^{\text {th. }}$ ed., Verlag C. H. Beck.

Hesse, Dirk (2007), § 1a, in: Ascheid, Preis, Schmidt, Kündigungsrecht, Verlag C. H. Beck.

Höland, Armin, Kahl, Ute and Nadine Zeibig (2007), Kündigungspraxis und Kündigungsschutz im Arbeitsverhältnis, Nomos Verlagsgesellschaft and Rainer Hampp Verlag.

Hoyningen-Huene, Gerrick von and Rüdiger Linck (2007), Kündigungsschutzgesetz Kommentar, $14^{\text {th. }}$ ed., Verlag C. H. Beck.

Jahn, Elke J. (2005), Wie wirkt der Kündigungsschutz?, Zeitschrift für Arbeitsmarktforschung 38(2-3), 284-304. 
Jahn, Elke J. (2009), Do Firms Obey the Law When They Fire Workers? - Social Criteria and Severance Payments in Germany, International Journal of Manpower 30(7), 672-691.

Jahn, Elke J. and Ulrich Walwei (2005), Kündigungsschutz - Nicht Kleckern, sondern Klotzen, IAB-Forum 1, 26-29.

Kögel, Andreas M. (2009), Der Abfindungsanspruch nach §1a KSchG, Recht der Arbeit, 358367.

Kortstock, Ulf (2007), Abfindung nach §1a KSchG und Betriebsübergang, Neue Zeitschrift für Arbeitsrecht, Issue 6, 297-301.

Maschmann, Frank (2003), Neuer gesetzlicher Abfindungsanspruch, Arbeit und Arbeitsrecht, Issue 10, 6-12.

May, Frank Christian and Horst Schellhaaß (2009), Reform des Kündigungsschutzes: Ein Weg zur mehr Beschäftigung?, Orientierungen zur Wirtschafts- und Gesellschaftspolitik 122 (4/2009), 21-27.

Merz, Christian (2006), Der Abfindungsanspruch des Arbeitnehmers nach §1a KSchG, Wissenschaftlicher Verlag Berlin.

OECD (2004), Employment Outlook, Chapter 2: Employment Protection Regulation and Labour Market Performance, 61-125, Paris.

Pannenberg, Markus, Pischner, Rainer, Rendtel, Ulrich, Spiess, Martin and Wagner, Gert (2005), Sampling and Weighting, in: Haisken-DeNew, John and Joachim R. Frick, (eds), Desktop Companion to the SOEP, Berlin.

Preis, Ulrich (2004), Die "Reform" des Kündigungsschutzes, Der Betrieb, Issue 1/2, 70-79.

Quecke, Martin (2004), Die Änderung des Kündigungsschutzgesetzes zum 1.1.2004, Recht der Arbeit, Issue 2, 86-106.

Raab, Thomas (2005), Der Abfindungsanspruch gemäß §1a KSchG, Recht der Arbeit, Issue 1, $1-12$.

Rolfs, Christian (2006), Der allgemeine Kündigungsschutz nach dem Gesetz zu Reformen am Arbeitsmarkt, Sozialer Fortschritt, Issue 2-3, 34-41.

Spilger, Andreas M. (2009), §1a Abfindungsanspruch bei betriebsbedingter Kündigung, in: Etzel, Gerhard et al. (eds), Gemeinschaftskommentar, $9^{\text {th. }}$ ed., Luchterhand-Verlag.

Tschöpe, Ulrich (2004), Neues Kündigungsschutzrecht 2004, Monatsschrift für Deutsches Recht, Issue 4, 193-201.

Wagner, Gerd G., Frick, Joachim R. and Jürgen Schupp (2007), The German Socio-Economic Panel Study (SOEP) - Scope, Evolution, and Enhancements, Schmollers Jahrbuch 127(1), 139-169.

Wolf, Alexander (2004), Die qualifizierte Abfindungsvereinbarung nach §1a KSchG - eher Steine als Brot für die Praxis, Betriebsberater, 378-381. 
Appendix

Table A1: Determinants of the Existence of a Works Council

\begin{tabular}{|lcc|}
\hline Variable & Coefficient & Standard Error \\
\hline Tenure of last job & $0.056^{*}$ & 0.023 \\
Firm size: $20 \leq \mathrm{X}<200$ employees & -0.099 & 0.681 \\
Firm size: $200 \leq \mathrm{X}<2000$ employees & 0.754 & 0.649 \\
Firm size: $\mathrm{X} \geq 2000$ employees & 0.632 & 0.729 \\
Other industries & 0.297 & 1.048 \\
Chemical industry & -0.022 & 0.698 \\
Retail/ Banking/ Insurance & 0.263 & 0.540 \\
Metal/ Electrical industry & $1.406^{*}$ & 0.573 \\
Public Sector/ Transport & $1.922^{* *}$ & 0.666 \\
Schleswig Holstein/ Hamburg & 0.564 & 0.589 \\
Lower Saxony & 0.424 & 0.601 \\
North Rhine Westphalia & 0.370 & 0.581 \\
Hesse & 0.689 & 0.689 \\
Rhineland-Palatinate/ Saarland & $1.341^{+}$ & 0.698 \\
Baden-Württemberg & 0.106 & 0.847 \\
Constant & $-1.96^{*}$ & 0.755 \\
\hline Wald_X (df) & \multicolumn{2}{c|}{$27.22^{*}(15)$} \\
Pseudo-R & \multicolumn{2}{c}{78} \\
Number of observations & 78 \\
\hline
\end{tabular}

Source: SOEP 2001 and 2006. Survey weights are used.

Probit-model with dependent variable: works council exists within firm (0/1)

Significance level: ** $(0.01), *(0.05),+(0.10)$. 


\section{CESifo Working Paper Series}

for full list see www.cesifo-group.org/wp

(address: Poschingerstr. 5, 81679 Munich, Germany, office@cesifo.de)

3057 Joseph Plasmans and Ruslan Lukach, The Patterns of Inter-firm and Inter-industry Knowledge Flows in the Netherlands, May 2010

3058 Jenny E. Ligthart and Sebastian E. V. Werner, Has the Euro Affected the Choice of Invoicing Currency?, May 2010

3059 Håkan Selin, Marginal Tax Rates and Tax-Favoured Pension Savings of the SelfEmployed - Evidence from Sweden, May 2010

3060 Richard Cornes, Roger Hartley and Yuji Tamura, A New Approach to Solving Production-Appropriation Games with Many Heterogeneous Players, May 2010

3061 Ronald MacDonald and Flávio Vieira, A Panel Data Investigation of Real Exchange Rate Misalignment and Growth, May 2010

3062 Thomas Eichner and Rüdiger Pethig, Efficient Management of Insecure Fossil Fuel Imports through Taxing(!) Domestic Green Energy?, May 2010

3063 Vít Bubák, Evžen Kočenda and Filip Žikeš, Volatility Transmission in Emerging European Foreign Exchange Markets, May 2010

3064 Leonid V. Azarnert, Après nous le Déluge: Fertility and the Intensity of Struggle against Immigration, May 2010

3065 William E. Becker, William H. Greene and John J. Siegfried, Do Undergraduate Majors or Ph.D. Students Affect Faculty Size?, May 2010

3066 Johannes Becker, Strategic Trade Policy through the Tax System, May 2010

3067 Omer Biran and Françoise Forges, Core-stable Rings in Auctions with Independent Private Values, May 2010

3068 Torben M. Andersen, Why do Scandinavians Work?, May 2010

3069 Andrey Launov and Klaus Wälde, Estimating Incentive and Welfare Effects of NonStationary Unemployment Benefits, May 2010

3070 Simon Gächter, Benedikt Herrmann and Christian Thöni, Culture and Cooperation, June 2010

3071 Mehmet Bac and Eren Inci, The Old-Boy Network and the Quality of Entrepreneurs, June 2010

3072 Krisztina Molnár and Sergio Santoro, Optimal Monetary Policy when Agents are Learning, June 2010 
3073 Marcel Boyer and Donatella Porrini, Optimal Liability Sharing and Court Errors: An Exploratory Analysis, June 2010

3074 Guglielmo Maria Caporale, Roman Matousek and Chris Stewart, EU Banks Rating Assignments: Is there Heterogeneity between New and Old Member Countries? June 2010

3075 Assaf Razin and Efraim Sadka, Fiscal and Migration Competition, June 2010

3076 Shafik Hebous, Martin Ruf and Alfons Weichenrieder, The Effects of Taxation on the Location Decision of Multinational Firms: M\&A vs. Greenfield Investments, June 2010

3077 Alessandro Cigno, How to Deal with Covert Child Labour, and Give Children an Effective Education, in a Poor Developing Country: An Optimal Taxation Problem with Moral Hazard, June 2010

3078 Bruno S. Frey and Lasse Steiner, World Heritage List: Does it Make Sense?, June 2010

3079 Henning Bohn, The Economic Consequences of Rising U.S. Government Debt: Privileges at Risk, June 2010

3080 Rebeca Jiménez-Rodriguez, Amalia Morales-Zumaquero and Balázs Égert, The VARying Effect of Foreign Shocks in Central and Eastern Europe, June 2010

3081 Stephane Dees, M. Hashem Pesaran, L. Vanessa Smith and Ron P. Smith, Supply, Demand and Monetary Policy Shocks in a Multi-Country New Keynesian Model, June 2010

3082 Sara Amoroso, Peter Kort, Bertrand Melenberg, Joseph Plasmans and Mark Vancauteren, Firm Level Productivity under Imperfect Competition in Output and Labor Markets, June 2010

3083 Thomas Eichner and Rüdiger Pethig, International Carbon Emissions Trading and Strategic Incentives to Subsidize Green Energy, June 2010

3084 Henri Fraisse, Labour Disputes and the Game of Legal Representation, June 2010

3085 Andrzej Baniak and Peter Grajzl, Interjurisdictional Linkages and the Scope for Interventionist Legal Harmonization, June 2010

3086 Oliver Falck and Ludger Woessmann, School Competition and Students' Entrepreneurial Intentions: International Evidence Using Historical Catholic Roots of Private Schooling, June 2010

3087 Bernd Hayo and Stefan Voigt, Determinants of Constitutional Change: Why do Countries Change their Form of Government?, June 2010

3088 Momi Dahan and Michel Strawczynski, Fiscal Rules and Composition Bias in OECD Countries, June 2010 
3089 Marcel Fratzscher and Julien Reynaud, IMF Surveillance and Financial Markets - A Political Economy Analysis, June 2010

3090 Michel Beine, Elisabetta Lodigiani and Robert Vermeulen, Remittances and Financial Openness, June 2010

3091 Sebastian Kube and Christian Traxler, The Interaction of Legal and Social Norm Enforcement, June 2010

3092 Volker Grossmann, Thomas M. Steger and Timo Trimborn, Quantifying Optimal Growth Policy, June 2010

3093 Huw David Dixon, A Unified Framework for Using Micro-Data to Compare Dynamic Wage and Price Setting Models, June 2010

3094 Helmuth Cremer, Firouz Gahvari and Pierre Pestieau, Accidental Bequests: A Curse for the Rich and a Boon for the Poor, June 2010

3095 Frank Lichtenberg, The Contribution of Pharmaceutical Innovation to Longevity Growth in Germany and France, June 2010

3096 Simon P. Anderson, Øystein Foros and Hans Jarle Kind, Hotelling Competition with Multi-Purchasing: Time Magazine, Newsweek, or both?, June 2010

3097 Assar Lindbeck and Mats Persson, A Continuous Theory of Income Insurance, June 2010

3098 Thomas Moutos and Christos Tsitsikas, Whither Public Interest: The Case of Greece's Public Finance, June 2010

3099 Thomas Eichner and Thorsten Upmann, Labor Markets and Capital Tax Competition, June 2010

3100 Massimo Bordignon and Santino Piazza, Who do you Blame in Local Finance? An Analysis of Municipal Financing in Italy, June 2010

3101 Kyriakos C. Neanidis, Financial Dollarization and European Union Membership, June 2010

3102 Maela Giofré, Investor Protection and Foreign Stakeholders, June 2010

3103 Andrea F. Presbitero and Alberto Zazzaro, Competition and Relationship Lending: Friends or Foes?, June 2010

3104 Dan Anderberg and Yu Zhu, The Effect of Education on Martial Status and Partner Characteristics: Evidence from the UK, June 2010

3105 Hendrik Jürges, Eberhard Kruk and Steffen Reinhold, The Effect of Compulsory Schooling on Health - Evidence from Biomarkers, June 2010 
3106 Alessandro Gambini and Alberto Zazzaro, Long-Lasting Bank Relationships and Growth of Firms, June 2010

3107 Jenny E. Ligthart and Gerard C. van der Meijden, Coordinated Tax-Tariff Reforms, Informality, and Welfare Distribution, June 2010

3108 Vilen Lipatov and Alfons Weichenrieder, Optimal Income Taxation with Tax Competition, June 2010

3109 Malte Mosel, Competition, Imitation, and R\&D Productivity in a Growth Model with Sector-Specific Patent Protection, June 2010

3110 Balázs Égert, Catching-up and Inflation in Europe: Balassa-Samuelson, Engel's Law and other Culprits, June 2010

3111 Johannes Metzler and Ludger Woessmann, The Impact of Teacher Subject Knowledge on Student Achievement: Evidence from Within-Teacher Within-Student Variation, June 2010

3112 Leif Danziger, Uniform and Nonuniform Staggering of Wage Contracts, July 2010

3113 Wolfgang Buchholz and Wolfgang Peters, Equity as a Prerequisite for Stable Cooperation in a Public-Good Economy - The Core Revisited, July 2010

3114 Panu Poutvaara and Olli Ropponen, School Shootings and Student Performance, July 2010

3115 John Beirne, Guglielmo Maria Caporale and Nicola Spagnolo, Liquidity Risk, Credit Risk and the Overnight Interest Rate Spread: A Stochastic Volatility Modelling Approach, July 2010

3116 M. Hashem Pesaran, Predictability of Asset Returns and the Efficient Market Hypothesis, July 2010

3117 Dorothee Crayen, Christa Hainz and Christiane Ströh de Martínez, Remittances, Banking Status and the Usage of Insurance Schemes, July 2010

3118 Eric O’N. Fisher, Heckscher-Ohlin Theory when Countries have Different Technologies, July 2010

3119 Huw Dixon and Hervé Le Bihan, Generalized Taylor and Generalized Calvo Price and Wage-Setting: Micro Evidence with Macro Implications, July 2010

3120 Laszlo Goerke and Markus Pannenberg, 'Take it or Go to Court' - The Impact of Sec. la of the German Protection against Dismissal Act on Severance Payments -, July 2010 